University at Buffalo School of Law

Digital Commons @ University at Buffalo School of Law

\title{
A Post-Vieth Strategy for Litigating Partisan Gerrymandering Claims
}

James A. Gardner

University at Buffalo School of Law

Follow this and additional works at: https://digitalcommons.law.buffalo.edu/journal_articles

Part of the Constitutional Law Commons, Election Law Commons, and the Litigation Commons

\section{Recommended Citation}

James A. Gardner, A Post-Vieth Strategy for Litigating Partisan Gerrymandering Claims, 3 Elec. L.J. 643 (2004).

Available at: https://digitalcommons.law.buffalo.edu/journal_articles/246

\section{IN COPYRIGHT}

This Article is brought to you for free and open access by the Faculty Scholarship at Digital Commons @ University at Buffalo School of Law. It has been accepted for inclusion in Journal Articles by an authorized administrator of Digital Commons @ University at Buffalo School of Law. For more information, please contact lawscholar@buffalo.edu. 


\title{
A Post-Vieth Strategy for Litigating Partisan Gerrymandering Claims
}

\author{
JAMES A. GARDNER
}

$\mathbf{F}^{\infty}$ OR NEARLy TWO DECADES, the U.S. Supreme Court has insisted that partisan gerrymandering - the drawing of election district boundaries with the deliberate purpose of helping or harming the fortunes of a particular political party-can in some circumstances violate the Equal Protection Clause of the U.S. Constitution. At the same time, the Court has failed to provide lower courts, legislatures, political parties and litigants with a coherent standard by which to evaluate the constitutionality of legislative redistricting plans. As a result, through two federal census cycles that have produced more than one hundred state legislative and U.S. congressional redistricting plans and thousands of county and municipal plans, no federal court has ever invalidated a legislative apportionment plan on the ground that it violated constitutional limits on partisan gerrymandering.

In this environment, the Court's decision this Term in Vieth $v$. Jubelirer, ${ }^{1}$ its first partisan gerrymandering case since 1986, was eagerly anticipated by state legislatures, political operatives, and redistricting consultants around the nation. The result was disappointing: a badly divided Court was unable to reach agreement on any new standard. To make matters worse, Justice Kennedy, who cast the swing vote, agreed with four justices that partisan gerrymandering may in principle violate the Constitution; agreed with four different justices that the prevailing Bandemer standard was unworkable; and then left the law a shambles by

James A. Gardner is Professor of Law, State University of New York, University at Buffalo Law School. declining even to speculate about how a judicially manageable standard might be framed to capture the distinction between permissible and forbidden reapportionment plans. Vieth thus appears to resolve nothing, while inviting litigants to continue bringing what have proven uniformly to be fruitless actions in the hope of stumbling blindly upon some legal standard that might supply the as-yet unknown incantation necessary to evoke judicial relief.

Despite the seeming hopelessness of the situation, Justice Kennedy's opinion in Vieth does, I believe, suggest a potentially fruitful strategy by which opponents of partisan gerrymandering may return to the Court in the not-too-distant future in a position of much greater strength. This strategy, however, requires election reform litigators to do something that they have long been extremely reluctant to do: try their luck in state courts, under provisions of state constitutions. The abandonment of federal court would not be permanent. I shall argue that Justice Kennedy's appeal in Vieth for a judicially manageable standard by which to evaluate partisan gerrymandering stands as an invitation to litigants to work at the state constitutional level to develop a nationwide consensus about how such claims should be handled. Once such a standard emerges from the pack-a process which need not take a great deal of time-litigants may then return to federal court well poised to argue for federal adoption of the consensus state-level standard. The Supreme Court has adopted state-level con-

\footnotetext{
${ }^{1} 124$ S.Ct. 1769 (2004).
} 
sensus standards as federal constitutional law in other contexts, including criminal procedure and due process, and there is no particular reason why the same strategy could not work for partisan gerrymandering claims.

In the balance of this article, I describe federal partisan gerrymandering jurisprudence from Bandemer to Vieth; explain the processes by which principles of state constitutional law can and frequently have influenced the content of federal constitutional law; and explore some of the avenues by which partisan gerrymandering claims might be advanced under state constitutions.

\section{PARTISAN GERRYMANDERING CLAIMS IN FEDERAL COURT}

The Court's first ruling dealing directly with partisan gerrymandering was its 1986 decision in Davis v. Bandemer, ${ }^{2}$ in which Indiana Democrats challenged a state legislative redistricting plan drawn by Republicans following the 1980 census. The Republican plan was used in the 1982 election cycle, resulting, Democrats claimed, in an unfair windfall of Republican seats statewide. The Court rejected the claim in a splintered opinion. Although six justices agreed that a partisan gerrymander violates the Equal Protection Clause if it involves "both intentional discrimination against an identifiable political group and an actual discriminatory effect on that group, ${ }^{3}$ they split decisively over how to operationalize this standard. A four-justice plurality held that partisan gerrymandering could be proven only by a showing of "continued frustration of the will of a majority of the voters or effective denial to a minority of voters of a fair chance to influence the political process."4 Because "continued" frustration could not be demonstrated by the results of a single election cycle, the plurality rejected the constitutional claim. ${ }^{5}$ Two other justices, in contrast, believed that the evidence was sufficient to show an impermissible exclusion of Democrats from the redistricting process, and a consequent loss of political influence that was constitutionally sufficient to make out a partisan gerrymandering claim. ${ }^{6}$ Three other justices dissented on the ground that partisan gerrymandering raises a nonjusticiable political question. $^{7}$
For eighteen years, lower federal courts struggled unsuccessfully to make sense of Bandemer. Denied a majority holding on the prevailing standard, lower courts tended to rely on the plurality's standard. ${ }^{8}$ This standard, however, proved so demanding that in nearly two decades of partisan gerrymandering litigation not a single plaintiff ever prevailed on such a claim. Dozens of redistricting plans were invalidated for violating the Equal Protection Clause on other grounds-most notably violation of the one-person, one-vote standard-and many plans were invalidated under the federal Voting Rights Act, but not a single plan was ever struck down for exceeding the bounds of permissible partisanship in drawing district lines.

In April 2004, the Court decided its second partisan gerrymandering case, Vieth $v$. Jubelirer, in which Pennsylvania Democrats challenged a congressional reapportionment plan drawn, following the 2000 census, by a Republicancontrolled legislature and signed by a Republican governor. Delivering another badly splintered opinion, the Court in Vieth did nothing to clear up the confusion, and indeed worsened it. A minority consisting of Justice Scalia, Chief Justice Rehnquist, Justice O'Connor and Justice Thomas ruled that all partisan gerrymandering claims should be dismissed as nonjusticiable for lack of a judicially manageable standard. A different minority, consisting of Justices Stevens, Souter, Ginsburg and Breyer, argued in four separate opinions that partisan gerrymandering claims are justiciable, and each advanced a standard for evaluating such claims. None of these standards commanded more than two votes.

In a notably wishy-washy opinion, Justice Kennedy provided the critical swing vote by splitting the difference between the two blocs. While acknowledging "weighty arguments for holding cases like these to be nonjusticiable,"

\footnotetext{
${ }^{2} 478$ U.S. 109 (1986).

${ }^{3} I d$. at 127 (plurality opinion of Justice White), 161 (concurring opinion of Justice Powell).

${ }^{4}$ Id. at 133 (White, J.).

${ }^{5}$ Id. at $134-37$.

${ }^{6}$ Id. at $173-78$ (Powell, J.).

${ }^{7} \mathrm{Id}$. at $144-45$ (O'Connor, J.).

${ }^{8}$ Vieth v. Jubelirer, 124 S.Ct. at 1777 (Scalia, J.)
} 
Justice Kennedy maintained nevertheless that such arguments "are not so compelling that they require us now to bar all future claims of injury from a partisan gerrymander." 9 Although willing to hold open the door to future partisan gerrymandering claims, Justice Kennedy was unwilling either to endorse any of the standards proposed by other justices or to propose any standard of his own; instead, he lamented the fact that "there are yet no agreed upon substantive principles of fairness in districting," and that as a result, "we have no basis on which to define clear, manageable, and politically neutral standards for measuring the particular burden a given partisan classification imposes on representational rights." 10 Nevertheless, Justice Kennedy did not find this uncertainty particularly troubling: "That no such standard has emerged in this case should not be taken to prove that none will emerge in the future."11 Consequently, he argued, the Court should not prematurely bar all partisan gerrymandering claims, but should be prepared to hear them "[i]f workable standards do emerge for measuring the burden a gerrymander imposes on representational rights."12

But how and from where might such standards emerge? Normally, the Supreme Court expects precise standards for constitutional injuries to emerge from the give and take of litigation in the lower federal courts. However, as Justice Scalia pointed out in Vieth, "[e]ighteen years of judicial effort" in the lower federal courts under the Bandemer standard has "virtually nothing to show for it."13 Nor, according to Justice Kennedy, can "helpful discussions on the principles of fair districting" be found "in the annals of parliamentary or legislative bodies." 14 There is, however, a potentially promising yet largely untried venue in which to develop the kind of standard Justice Kennedy apparently seeks: state courts.

\section{INFLUENCING FEDERAL CONSTITUTIONAL DOCTRINE THROUGH STATE CONSTITUTIONAL LAW}

Every state has its own constitution, and each state constitution provides at least some, and in most cases, extensive protection for individ- ual rights. ${ }^{15}$ For the most part, state constitutional rights provisions tend to resemble counterpart provisions in the U.S. Constitution, and consequently tend to protect more or less the same rights that appear in the federal document. Moreover, state courts often look to the U.S. Supreme Court for guidance in interpreting parallel provisions of their own constitutions, and consequently the dominant pattern among state bills of rights is one of similar provisions, similarly interpreted. ${ }^{16}$

There are, however, important exceptions to the general pattern. First, state constitutions frequently contain provisions that have no counterpart in the U.S. Constitution. Such provisions sometimes include the right to an adequate education, the right to a judicial remedy for injuries and other wrongs, and, perhaps significantly, the rights to vote and to free and fair elections. Second, even when state constitutional rights provisions bear a textual similarity to provisions of the U.S. Constitution, state courts are free to interpret them differently, and have often done so.

State constitutions are independent bodies of law, and their meaning therefore does not depend upon the meaning of other provisions appearing in other constitutions, no matter how similar the text. ${ }^{17}$ State courts consequently may interpret such provisions in whatever way they think best, and have on many occasions exercised their independent judgment to read provisions of state constitutions differently from, and often more generously than, the U.S. Supreme Court has read similar provisions of the federal Constitution, a phenomenon often known as the "New Judicial Federalism." ${ }^{18}$ For example, courts in five states have held, con-

\footnotetext{
${ }^{9}$ Id. at 1794 (Kennedy, J.).

${ }^{10}$ Id. at 1793 .

${ }^{11}$ Id. at 1795 .

${ }^{12} \mathrm{Id}$. at 1799.

${ }^{13}$ Id. at 1778 (Scalia, J.).

${ }^{14} I d$. at 1794 (Kennedy, J.).

${ }^{15} \mathrm{G}$. Alan Tarr, Understanding State Constitutions (Princeton: Princeton University Press, 1998), 11-13.

${ }^{16} I d$. at 39-55.

${ }^{17}$ William J. Brennan, Jr., State Constitutions and the Protection of Individual Rights, 90 Harv. L. Rev. 489 (1977); Hans Linde, First Things First: Rediscovering the States' Bills of Rights, 9 U. Balt. L. Rev. 379 (1980).

${ }^{18}$ Tarr, supra note 15 , at $161-70$.
} 
trary to the U.S. Supreme Court, that the free speech provisions of their state constitutions protect a right to speak in privately owned shopping malls. ${ }^{19}$ Numerous state courts have rejected, under state constitutional provisions barring unreasonable searches and seizures, the Supreme Court's ruling that a canine sniff does not amount to a constitutionally cognizable "search." 20 The highest courts of California and New York have interpreted their state constitutions to prohibit warrantless aerial searches, rejecting the U.S. Supreme Court's interpretation of the Fourth Amendment. ${ }^{21}$

These kinds of independent-minded state constitutional rulings require state officials to adhere to different, and in many cases more demanding, constraints in the performance of their constitutional duties, and are for that reason alone potentially significant avenues by which to address problems raised by partisan gerrymandering. But state court rulings under state constitutions also have another kind of impact that makes them doubly useful: they can, in the long run, influence the content of federal constitutional law, thereby altering the constitutional rules governing the behavior of federal officials and, by operation of the Fourteenth Amendment, of state officials in states other than those in which the rulings originate.

State constitutional rulings can influence the content of federal constitutional law in at least two ways, one weak and one strong. The weaker of the two forms of influence consists simply of persuasion. Over the past twenty or thirty years, legal scholars have come increasingly to accept a "dialogic" model of legal meaning. ${ }^{22}$ According to this model, federal courts do not sit in splendid, ivory-tower isolation, interpreting the Constitution through the independent identification and elaboration of constitutional first principles. Rather, constitutional meaning is understood to emerge from a conversation, sometimes collaborative and sometimes adversarial, among numerous interpreters, including Congress, the executive branch, lower federal courts, and state judiciaries. In this system, the U.S. Supreme Court may occupy a privileged position as the final arbiter of constitutional meaning, but it enjoys no special privilege in the generation of constitutional meaning.
State courts engage in this dialogue concerning the meaning of federal constitutional law most directly, of course, when they interpret provisions of the federal Constitution, but they also do so when they interpret provisions of their own state constitutions. Perhaps the most visible engagement of this type occurs when a state court gives a provision of the state constitution an interpretation different from the one the U.S. Supreme Court has given a textually similar provision of the U.S. Constitution. In declining to follow the Supreme Court, a state supreme court may register a forceful public dissent, arguing in essence that the Supreme Court has failed to capture correctly the meaning of a jointly protected constitutional right. ${ }^{23}$ Ultimately, this kind of interjudicial dialogue may help persuade the Court that it has erred.

State constitutional rulings may also influence the content of federal constitutional law in a stronger way: by contributing to the establishment of a nationwide legal consensus at the state level. Such a consensus can be significant for federal constitutional law because fed-

${ }^{19}$ Compare Hudgens v. NLRB, 424 U.S. 507 (1976), with Robins v. Pruneyard Shopping Center, 592 P.2d 341 (Cal. 1979), aff'd, 447 U.S. 74 (1980); Bock v. Westminster Mall Co., 819 P.2d 55 (Colo. 1991); Batchelder v. Allied Stores International, 445 N.E.2d 590 (Mass. 1983); New Jersey Coalition Against War in the Middle East v. J.M.B. Realty Corp., 650 A.2d 757 (N.J. 1994); Alderwood Assocs. v. Washington Environmental Council, 635 P.2d 108 (Wash. 1981).

${ }^{20}$ Compare United States v. Place, 462 U.S. 696 (1983), with, e.g., McGahan v. State, 807 P.2d 506 (Alaska App. 1991); People v. Unruh, 713 P.2d 370 (Colo. 1986); State v. Pellicci, 580 A.2d 710 (N.H. 1990); People v. Dunn, 564 N.E.2d 1054 (N.Y. 1990); Commonwealth v. Johnston, 530 A.2d 74 (Pa. 1987).

${ }^{21}$ Compare California v. Ciraolo, 476 U.S. 207 (1986), with People v. Cook, 710 P.2d 299 (Cal. 1985); People v. Scott, 593 N.E.2d 1328 (N.Y. 1992).

${ }^{22}$ In the context of federalism specifically, see Robert M. Cover and T. Alexander Aleinikoff, Dialectical Federalism: Habeas Corpus and the Court, 86 Yale L. J. 1035 (1977); Barry Friedman, Dialogue and Judicial Review, 91 Mich. L. Rev. 577 (1993); Robert A. Schapiro, Polyphonic Federalism: State Constitutions in the Federal Courts, 87 Cal. L. Rev. 1409 (1999); Lawrence Friedman, The Constitutional Value of Dialogue and the New Judicial Federalism, 28 Hastings Const. L. Q. 93 (2000).

${ }^{23}$ James A. Gardner, State Constitutional Rights as Resistance to National Power: Toward a Functional Theory of State Constitutions, 91 Geo. L. J. 1003, 1033-37 (2003). 
eral courts sometimes look to statewide agreement as evidence of national trends, beliefs, and traditions. These beliefs and traditions may then in turn be incorporated into federal constitutional law as baselines for federal constitutional decision making, most notably in adjudicating due process rights under the Fourteenth Amendment. Perhaps the classic example of this process is the Supreme Court's decision in Mapp v. Ohio, ${ }^{24}$ which holds that the Due Process Clause requires states to apply the exclusionary rule to unconstitutionally seized evidence. A significant basis for this ruling was the emergence of a consensus among state courts that exclusion was the only workable remedy for police violations of constitutional prohibitions against unreasonable searches and seizures. The emergence of this consensus, the Court held, was sufficient to allow it to determine that the exclusion of unconstitutionally seized evidence was, contrary to a prior decision, which it overruled, an aspect of the ordered liberty protected by the Due Process Clause. ${ }^{25}$

Since Mapp, the Court has turned increasingly to state constitutional law to provide a baseline against which to measure whether any particular individual right can be considered part of the fundamental liberty protected by the federal Constitution. ${ }^{26}$ Most recently, and dramatically, the Court in Lawrence v. Texas ${ }^{27}$ reversed its decision in Bowers v. Hardwick ${ }^{28}$ and invalidated on due process grounds a state law criminalizing homosexual conduct. In reaching this decision, the Court relied in part on an examination of state practice and policy following its ruling in Bowers, during the course of which it noted that no fewer than five state appellate courts had explicitly rejected Bowers as a guide for construing due process and privacy provisions of their state constitutions. ${ }^{29}$

This process of intersystemic judicial dialogue and influence need not take a long time to bear fruit, at least as judged by the deliberate standards of constitutional jurisprudence. The time elapsed between the Supreme Court's decision in Wolf v. Colorado, 30 in which the Court held that the exclusion of unconstitutionally seized evidence was not part of the ordered liberty protected by the Due Process Clause, and its decision in Mapp holding the opposite, was just twelve years. The Court decided Bowers in 1986, but reversed itself in Lawrence just seventeen years later. The state constitutional decisions rejecting Bowers upon which the Court relied were decided in only a ten-year span, from 1992 to 2002. Considering that the Court tends to measure the constitutional protections of due process in terms of tradition and history, this is rapid progress indeed.

These considerations suggest that a state constitutional litigation strategy may feasibly revive the prospects for the kind of challenge to partisan gerrymandering that has never succeeded in federal court and for which the Court's decision in Vieth offered little hope. A closer examination of state constitutions suggests that there might indeed be grounds for optimism. ${ }^{31}$

\section{MOUNTING A PARTISAN GERRYMANDERING CLAIM UNDER STATE CONSTITUTIONS}

One of the great disadvantages of litigating electoral and political issues under the federal Constitution is that the Constitution has comparatively little to say about the electoral process. For example, it confers no affirmative right to vote for any office; does not regulate in any significant way the course of democratic politics; and does not rest upon any clearly ar-

\footnotetext{
24367 U.S. 643 (1961).

${ }^{25} \mathrm{Id}$. at $657-58$.

${ }^{26}$ See Gardner, supra note 23 , at 1040-43.

27539 U.S. 558 (2003).

${ }^{28} 478$ U.S. 186 (1986).

29539 U.S. at 576.

30338 U.S. 25 (1949).

${ }^{31}$ I take it as a given, for purposes of this analysis, that judicial intervention to curb partisan gerrymandering could be a good thing. There is, of course, a respectable view to the contrary, not only on the Court, but in the legal academy as well. See, e.g., Daniel H. Lowenstein and Jonathan Steinberg, The Quest for Legislative Districting in the Public Interest: Elusive or Illusory?, 33 UCLA L. Rev. 1 (1985); Peter H. Schuck, The Thickest Thicket: Partisan Gerrymandering and Judicial Regulation of Politics, 87 Colum. L. Rev. 1325 (1987); Nathaniel Persily, In Defense of Foxes Guarding Henhouses: The Case for Judicial Acquiescence to Incumbent-Protecting Gerrymanders, 116 Harv. L. Rev. 649 (2002).
} 
ticulated conception of political life, other than perhaps an eighteenth-century republican conception that the nation has long outgrown. ${ }^{32}$ State constitutions typically do not share these drawbacks. Most contain numerous provisions affirmatively ordering and protecting the electoral process; many contain provisions specifically regulating apportionment; and many reflect overtly contemporary conceptions of politics informed by movements ranging from early twentieth-century Progressivism to more recent models of egalitarian political participation and influence. These features make state constitutions potentially rich veins to be mined by opponents of partisan gerrymandering. ${ }^{33}$

As the Supreme Court has said on many occasions, the U.S. Constitution "does not confer the right the right of suffrage upon any one." 34 Instead, the Constitution protects only a derivative right of equal treatment in voting that is parasitic on state constitutional standards. ${ }^{35} \mathrm{In}$ deed, because the Constitution specifically allocates the establishment of voting rights in federal elections to the states, ${ }^{36}$ state constitutions establish the right to vote not only in state and local elections, but in federal elections as well. Typically, state constitutions provide the right to vote to any person who meets the constitutional requirements of eligibility, which most often include citizenship, age, and residency. ${ }^{37}$

Moreover, again unlike the U.S. Constitution, most state constitutions provide some form of affirmative protection for the right to vote. For example, the constitutions of eight states require elections to be "free," thirteen state constitutions require elections to be "free and equal," and five require elections to be "free and open." 38 The constitutions of Massachusetts, New Hampshire, and South Carolina provide specifically that all qualified voters have an equal right to vote or to elect officers. ${ }^{39}$ The West Virginia Constitution provides that every citizen is entitled to equal representation in government. ${ }^{40}$ The constitutions of numerous states require the state legislature to enact laws to secure the "purity" or "integrity" of elections, to "guard against abuses," to provide for "free" elections, or to prevent "corruption." 41

\footnotetext{
${ }^{32}$ See James A. Gardner, Madison's Hope: Virtue, Self-Interest, and the Design of Electoral Systems, 86 Iowa L. Rev. 87, 126-30 (2000).

${ }^{33}$ In suggesting that partisan gerrymandering litigators turn to state constitutions, I mean to argue only for a particular litigation strategy, not for any particular standard of judicial review. I make no claim here to any insight into which standard might prove most appealing to state judges. Courts and commentators have proposed numerous ways in which to adjudicate the constitutionality of partisan gerrymandering claims, and unless it really is the case that no partisan gerrymandering standard could ever be judicially manageable, I assume that at least some of the standards that have been previously proposed will have sufficient appeal to stand a chance of adoption by state courts. For a sampling of such standards, see, in addition to the various opinions in Vieth and Bandemer, Bernard Grofman's useful overview in An Expert Witness Perspective on Continuing and Emerging Voting Rights Controversies: From One Person, One Vote to Partisan Gerrymandering, 21 Stetson L. Rev. 783 (1992). According to Grofman, most of the standards that have been proposed rely on some variant of either visual irregularity, deviations from proportionality, bias in seatvote ratios, discriminatory treatment of incumbents of the minority party, or the totality of the circumstances. In addition, some commentators have proposed procedural solutions, such as reliance on nonpartisan districting commissions, Samuel Issacharoff, Gerrymandering and Political Cartels, 116 Harv. L. Rev. 593 (2002), or requiring bipartisan compromise in the creation of plans, Michael E. Lewyn, How to Limit Gerrymandering, 45 Fla.
}

L. Rev. 403 (1993).

${ }^{34}$ Minor v. Happersett, 88 U.S. 162, 178 (1874).

${ }^{35}$ Dunn v. Blumstein, 405 U.S. 330, 336 (1972).

${ }^{36}$ U.S. Const. Art. I, § 2, cl. 1.

${ }^{37}$ See, e.g., Maine Const. art. II, § 1; N.D. Const. art. II, § 1; Va. Const. art. II, § 1.

38 "Free": Cal. Const. art. IV, § 1.5; Mass. Const. Part the First, art. IX; Neb. Const. art. 1, § 22; N.H. Const. Part the First, art. 11; N.C. Const. art. I, § 10; Utah Const. art. I, § 17; Vt. Const. ch. I, art. 8; Va. Const. art. I, § 6. "Free and equal": Ariz. Const. art. II, § 21; Ark. Const. art. 3, § 2; Del Const. art. I, § 3; Ill. Const. art. III, § 3; Ind. Const. art. 2, $\S 1$; Ky. Const. § 6; Okla. Const. art. III, § 5; Or. Const. art. II, § 1; Pa. Const. art. I, § 5; S.D. Const. art. VI, § 19; Tenn. Const. art. I, § 5; Wash. Const. art. I, § 19; Wy. Const. art. $1, \S 27$. "Free and open": Col. Const. art. II, § 5; Mo. Const. art. I, $\S 25$, art. VI, § 18(e) (county elections); Mont. Const. art. II, § 13; N.M. Const. art. II, § 8; S.C. Const. art. I, § 5. ${ }^{39}$ Mass. Const. Part the First, art. IX; N.H. Const. Part the First, art. 11; S.C. Const. art. I, § 5.

${ }^{40}$ W.Va. Const. art. II, § 2-4.

${ }^{41}$ Secure purity or integrity of elections and/or guard against abuses: Ariz. Const. art. VII, $\S 12$; Colo. Const. art. VII, § 11; Del Const. art. V, § 1; Ill. Const. art. III, § 4; Md. Const. art. I, § 1.7; Mich. Const. art. II, § 4; Mont. Const. art. IV , § 3; Nev. Const. art. 2, § 6; N.M. Const. art. VII, § 1; S.D. Const. art. VII, § 2; Tenn. Const. art. IV, § 1; Tex. Const. art. 6, § 4; Wyo. Const. art. 6, § 13. Provide for free elections or suffrage: Cal. Const. art. II, § 3, art. VII, § 8; Conn. Const. art. VI, § 4; Del. Const. art. V, § 1; Ky. Const. $\S 150 ;$ Or. Const. art. II, § 8. Prevent corruption: Del. Const. art. V, § 1; W.Va. Const. art. IV, § 4-11. 
In the case of gerrymandering, most state constitutions supplement these general principles of fair elections with specific provisions regulating the apportionment process, including the way in which election district boundaries must be drawn. For example, many such provisions require district lines to respect the integrity of local government boundaries. ${ }^{42}$ The great majority of state constitutions contain specific requirements that election districts be "contiguous" and "compact." 43 Six state constitutions require districts to be "convenient." 44 The Colorado Constitution is even more specific, requiring that "the aggregate linear distance of all district boundaries shall be as short as possible." 45 Michigan additionally requires certain districts to be "as rectangular" and "as nearly uniform in shape as possible." 46

Perhaps the most rigorous state constitutional regulation of the apportionment process requires that election districts be coherent political communities. The Alaska Constitution provides that legislative districts should contain "as nearly as practicable a relatively integrated socio-economic area." 47 The Hawaii Constitution similarly provides: "submergence of an area in a larger district wherein substantially different socio-economic interests predominate shall be avoided." 48 More comprehensively, the Colorado Constitution provides: "communities of interest, including ethnic, cultural, economic, trade area, geographic, and demographic factors, shall be preserved within a single district wherever possible." 49 Delaware, Hawaii, and Washington try to achieve fairness in redistricting even more directly by requiring that districts not unduly favor or discriminate against any person, group, or political party. ${ }^{50}$

Finally, even where state constitutions lack specific provisions regulating the electoral process, or where the relevant provisions are vague, additional guidance concerning the constitutional structure of the electoral system may sometimes be found in political theories that have influenced the evolution of American state constitutions. For purposes of partisan gerrymandering, one of the most important of these theories is Progressivism, which left a deep imprint on many state constitutions during the early twentieth century. ${ }^{51}$ One of Progressivism's fundamental principles was a deep skepticism of incumbency, born in the belief that government at the turn of the twentieth century was in the grasp of a corrupt economic elite that used governmental power both to enrich itself and to entrench its own hold over the levers of power. ${ }^{52}$ Progressives accordingly sought to reform state and local government by creating institutions of direct democracy, such as the initiative, referendum, and recall election, which would allow ordinary voters to thwart plans by incumbent power-holders to serve their own interests and to assure their own continuation in office. ${ }^{53} \mathrm{In}$ those states in which Progressives succeeded in institutionalizing reform at the constitutional level, state constitutions may thus quite plausibly be understood to embody a strong preference for electoral responsiveness to the popular will, and a corresponding suspicion of official manipulation of the rules of electoral engagement. More recently, some state constitutions have been amended to enact term limits and campaign finance reform, ${ }^{54}$ measures that further reflect popular suspicion of incumbents as well as a popular preference for fair, egalitarian, and competitive electoral contests among candidates for political office.

${ }^{42}$ E.g., Neb. Const. art. 3, § 5, art. VII, § 10; Pa. Const. art. II, § 16; Vt. Const. ch. II, § 18 .

${ }^{43}$ E.g., Alaska Const. art. VI, § 6; Colo. Const. art. V, § 47; N.Y. Const. art. III, § 4.

${ }^{44}(1)$ Mich. Const. art. IV, §§ 2, 3; (2) Minn. Const. art. IV, § 3; (3) Mo. Const. art. III, § 5; (4) N.Y. Const. art. III, § 5; (5) Wash. Const. art. II, $\S \S 6,43(5)$; (6) Wis. Const. art. IV, $\S 5$.

${ }^{45}$ Colo. Const. art. V, $\S 47(1)$.

${ }^{46}$ Mich. Const. art. IV, § 2.

${ }^{47}$ Alaska Const. art. VI, $\S 6$.

${ }^{48}$ Hawaii Const. art. IV, § 6(8).

${ }^{49}$ Colo. Const. art. V, § 47(3).

${ }^{50}$ Del. Const. art. II, § 2A; Haw. Const. art. IV, § 6; Wash. Const. art. II, § 43(5).

${ }^{51}$ Tarr, supra note 15 , at 150-53.

${ }^{52}$ See, e.g., Benjamin Parke DeWitt, The Progressive Movement (New York: Macmillan, 1915); Richard Hofstadter, The Age of Reform: From Bryan to F.D.R. (New York: Knopf, 1955); Joseph P. Harris, California Politics (4th edition) (San Francisco: Chandler Publishing Co., 1967).

${ }^{53}$ De Witt, supra note 52.

${ }^{54}$ Term limits: E.g., Cal. Const. art. 4, § 1.5; Mich. Const. art. IV , § 54; Ohio Const. art. 2, § 2, art. 3, § 2. Campaign finance: E.g., Ariz. Const. art. VII, $\S 16$; Colo. Const. art. XVIII; Nev. Const. art. 2, § 10; Okla. Const. art. IX, § 40; Or. Const. art. II, § 22; R.I. Const. art. IV, § 10. 
These provisions and background political theories could obviously be of great value in any challenge to partisan gerrymandering under a state constitution. The existence of an affirmative, constitutionally guaranteed right to vote could serve as an anchor for advancing a challenge to partisan gerrymandering on the ground that it is fundamentally antidemocratic. State constitutional requirements that elections be "free" or "fair" or "equal" might provide purchase in challenging partisan gerrymandering as a form of incumbent self-protection. Provisions governing the shape and composition of electoral districts might be invoked to challenge specific districts as well as entire redistricting plans. And all of these approaches could be reinforced by reference to constitutional background principles disfavoring electoral unresponsiveness and incumbency protection.

It bears repeating here that state constitutional law is independent of federal constitutional law, and state courts are thus in no way constrained by the various approaches to partisan gerry- mandering articulated by the U.S. Supreme Court justices who wrote opinions in Bandemer and Vieth. State courts considering claims of partisan gerrymandering might of course find useful guidance in federal case law, and if they thought some particular opinion to be especially valuable might conceivably adopt its analysis for purposes of state constitutional law; this has certainly been the dominant pattern in other areas. ${ }^{55}$ But state judges might just as easily strike off on their own, crafting a standard based on an independent analysis of the problem or tailoring it to whatever specific requirements the state constitution might uniquely impose.

In fairness, it must be noted that state courts have not thus far taken a particularly active role in using state constitutions to police state political processes in general, or partisan gerrymandering in particular. ${ }^{56}$ Many of the provisions mentioned above are, by federal standards, surprisingly underinterpreted and underenforced. ${ }^{57}$ On the other hand, most provisions of state constitutions, except perhaps those

\footnotetext{
${ }^{55}$ See, e.g., Barry Latzer, The Hidden Conservatism of the State Court "Revolution," 74 Judicature 190 (1991); James N. G. Cauthen, Expanding Rights Under State Constitutions: A Quantitative Appraisal, 63 Albany Law Review 1183 (2000).

${ }^{56}$ Although many state appellate courts have heard challenges to redistricting plans based on claims of partisan gerrymandering, no state court has as yet attempted to develop an independent state constitutional standard for analyzing such claims. The closest approach to such a standard has been made by the Alaska Supreme Court. In a series of cases, that court has ruled that the Alaska Constitution's equal protection provision sets a more demanding standard than the Fourteenth Amendment in that it not only creates a group-based right to representation, but also requires something resembling proportionality of representation in districting. However, although the court has applied this principle to invalidate redistricting plans for diluting the representation of voters identified geographically, it has never applied this analysis to groups of voters identified in terms of partisan loyalty. See Hickel v. Southeast Conference, 846 P.2d 38 (Alaska 1992); Kenai Peninsula Borough v. State, 743 P.2d 1352 (Alaska 1987). At the other end of the spectrum, the Pennsylvania Supreme Court has held that the Pennsylvania Constitution's equal protection provision means exactly the same thing as the Fourteenth Amendment, and has expressly adopted the Bandemer approach to partisan gerrymandering claims brought under the state constitution. Erfer v. Commonwealth, 794 A.2d 325, 331-32 (Pa. 2002).

In another group of cases, state courts have recognized that partisan gerrymandering claims may be raised under the state constitution, but have chosen to analyze such

claims solely under specific state constitutional provisions expressly requiring compactness, contiguity, or socio-economic coherence in the drawing of legislative district lines. See, e.g., In re Colorado General Assembly, 828 P.2d 185 (Colo. 1992); In re Legislative Districting, 805 A.2d 292, 320 (Md. 2002). These cases probably should not be read to hold that claims of partisan gerrymandering are exhausted by analysis of district compactness and contiguity; more likely, litigants charging partisan gerrymandering simply chose to couch their claims so as to raise issues only under explicitly articulated state constitutional requirements.

Finally, there is a large class of state constitutional cases in which, all too typically, state courts relying on Bandemer to resolve partisan gerrymandering claims have been ambiguous about whether their analyses apply solely to claims under the federal Constitution or also to parallel claims brought under the state constitution. See, e.g., Jensen v. Kentucky State Board of Elections, 959 S.W.2d 771 (Ky. 1997); Kendall v. Douglas, Grant, Lincoln \& Okanogan Counties Public Hospital District No. 6, 820 P.2d 497 (Wash. 1991). On the unhelpful tendency of state courts to be ambiguous about whether they are analyzing issues under the state or federal constitutions, or both, see James A. Gardner, The Failed Discourse of State Constitutionalism, 90 Mich. L. Rev. 761, 785-88 (1992).

${ }^{57}$ See, e.g., Matthew C. Jones, Fraud and the Franchise: The Pennsylvania Constitution's "Free and Equal Election" Clause as an Independent Basis for State and Local Election Challenges, 68 Temple L. Rev. 1473 (1995); Richard H. Pildes and Richard G. Niemi, Expressive Harms, "Bizarre Districts," and Voting Rights: Evaluating Election-District Appearances after Shaw v. Reno, 92 Mich. L. Rev. 483, 528 (1993).
} 
dealing with criminal procedure, which forms a large part of the state constitutional caseload, tend to be sparsely interpreted, so the absence of an extensive body of case law on which to base a partisan gerrymandering claim need not indicate a judicial reluctance to engage state constitutional electoral provisions. If anything, a trend may well be emerging in which state courts are increasingly adjudicating challenges under provisions of state constitutions regulating apportionment. In the most recent redistricting cycle, for example, courts in Colorado, Mississippi, North Carolina, and Virginianone of which has a supreme court with a strong record of active reliance on its state constitution-all issued opinions providing new and important guidance concerning the meaning of state constitutional provisions regulating the redistricting process. ${ }^{58}$

Vieth itself, moreover, may make state courts more willing to turn to their state constitutions to settle questions arising out of the apportionment process. Although state courts have sometimes been reflexively-many would say excessively-deferential to federal decisional law when construing state constitutions, ${ }^{59}$ much of this deference may be attributable to a feeling among state judges that the federal judiciary typically does a more or less adequate job of protecting individual rights and that there is thus no pressing need for state intervention under state constitutions. ${ }^{60}$ In contrast, state courts have been a good deal more will- ing to act when they see themselves as the last line of defense in areas where the federal courts

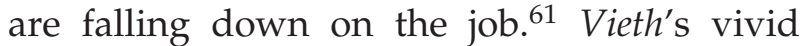
demonstration of the Supreme Court's continued paralysis might well serve as convincing evidence to state courts that they are the only institution left capable of restraining excessive partisan gerrymandering, and this knowledge might well prompt them to enter the fray.

One possible impediment to aggressive state judicial intervention in gerrymandering cases is that state judges, who are frequently elected, may be more dependent on maintaining the favor of political parties and legislative party leaders than federal judges. There is some systematic evidence that elected judges are less likely than appointed judges to take controversial positions, ${ }^{62}$ and certainly ample anecdotal evidence, such as California's infamous 1986 judicial retention election unseating three state supreme court justices, of popular backlashes against elected judges that have the potential to inhibit judicial independence. Yet most of this evidence is relevant only to situations in which state judges might be hesitant to construe the state constitution to reach democratically unpopular results. However unpopular state judicial restraint of partisan gerrymandering might be with party and legislative leaders, there is very little likelihood that it will prove unpopular with voters. State polities have long been highly suspicious of state legislatures, a sentiment made all too clear by the

\footnotetext{
58 Salazar v. Davidson, 79 P.3d 1221 (Colo. 2003) (construing provisions of state constitution governing frequency of redistrictings); Mauldin v. Branch, 866 So. 2d 429 (Miss. 2003) (construing jurisdiction of lower courts to supervise congressional redistricting); Stephenson v. Bartlett, 582 S.E.2d 247 (N.C. 2003) (interpreting provision of state constitution prohibiting division of counties in redistricting); West v. Gilmore, 2002 Va. Cir. LEXIS 37 (Va. Cir. Ct., March 10, 2002) (construing state constitutional requirements that election districts be contiguous and barring racial discrimination in redistricting).

${ }^{59}$ E.g., Brennan, supra note 17 , at 502; Robert F. Williams, In the Supreme Court's Shadow: Legitimacy of State Rejection of Supreme Court Reasoning and Result, 35 South Carolina Law Review 353, 356 (1984).

${ }^{60}$ Gardner, supra note 23 , at 1061. See also Stewart G. Pollack, State Constitutions as Separate Sources of Fundamental Rights, 35 Rutgers L. Rev. 707 (1983).

${ }^{61}$ This was of course the essence of Justice Brennan's famous appeal to state courts to "step into the breach."
}

Brennan, supra note 17 , at 503 . Some evidence of this approach might be found, for example, in state courts' frequent rejection of Rehnquist Court decisions cutting back on the scope of Fourth Amendment protections. Compare, for instance, Illinois v. Gates, 462 U.S. 213 (1983), relaxing the requirements for obtaining a warrant on the testimony of an anonymous informant, with its frequent rejection by state courts under state constitutions: State v. Jones, 706 P.2d 317 (Alaska 1985); People v. Campa, 686 P.2d 634 (Cal. 1984); Commonwealth v. Upton, 476 N.E.2d 548 (Mass. 1985); State v. Cordova, 784 P.2d 30 (N.M. 1989); People v. Griminger, 524 N.E.2d 409 (N.Y. 1988); State v. Jacumin, 778 S.W.2d 430 (Tenn. 1989); State v. Jackson, 688 P.2d 136 (Wash. 1984).

${ }^{62}$ Paul Brace, Melinda Gann Hall, and Laura Langer, Judicial Choice and the Politics of Abortion: Institutions, Context, and the Autonomy of Courts, 62 Albany Law Review 1265 (1999); Melinda Gann Hall, Electoral Politics and Strategic Voting in State Supreme Courts, 54 Journal of Politics 427 (1992). 
extensive state constitutional record of cumulative restrictions on state legislative power. ${ }^{63}$ More to the point, voters in many states, particularly those with initiative and referendum procedures, have been trying for some time now to reform a political process with which they are clearly disgusted, efforts that have often been thwarted by federal courts. ${ }^{64}$ State judicial restraint of excessively partisan gerrymandering, and the frequently uncompetitive and unrepresentative districts it creates, would very likely please voters, reducing any inhibitions elected judges might otherwise feel.

\section{CONCLUSION}

Given the Supreme Court's equivocal ruling in Vieth, a litigation strategy challenging partisan gerrymandering in state courts under state constitutions might be the most promising way to elicit meaningful judicial intervention. State constitutions offer significant opportunities for successful challenges to partisan gerrymandering, and well-established patterns in the development of state constitutional jurisprudence suggest that many state courts might be open to resolving such claims. Of course, sustained success in state courts might in the long run render any federal constitutional law of partisan gerrymandering largely irrelevant. Even so, state constitutional rulings might also in- fluence the content of federal constitutional standards by providing a state-level consensus baseline suitable for adoption by federal courts in partisan gerrymandering cases arising under the U.S. Constitution. Through such a process, state constitutional standards, shaped by statelevel election reform litigation, may be reintroduced into federal constitutional law in the form of nationally binding standards of legislative reapportionment.

Address correspondence to: James A. Gardner State University of New York University at Buffalo School of Law Room 514, O'Brian Hall Buffalo, NY 14260-1100

E-mail: jgard@buffalo.edu

${ }^{63}$ Tarr, supra note 15 , at $117-26$.

${ }^{64}$ Some of these measures include term limits, blanket primaries, and campaign finance reform. Many of these innovations have been invalidated by federal courts. See, e.g., U.S. Term Limits v. Thornton, 514 U.S. 779 (1995) (invalidating state-imposed term limits on members of Congress); California Democratic Party v. Jones, 530 U.S. 567 (2000) (invalidating a blanket primary where it was opposed by a major political party); Vanatta v. Keisling, 899 F. Supp. 488 (D. Or. 1995), aff'd, 151 F.3d 1215 (9th Cir. 1998), cert. denied, 525 U.S. 1104 (1999) (invalidating Oregon provision prohibiting candidates for state office to expend funds donated by nonresidents). 